\title{
HUBUNGAN GAYA KEPEMIMPINAN DAN IKLIM KOMUNIKASI ORGANISASI: \\ KASUS PADA BRI KANCA MADIUN DI MASA PANDEMI
}

\author{
Nurullita Mutia Andina ${ }^{1}$, Emeraldy Chatra $^{2}$, Asmawi $^{3}$ \\ Program Magister Ilmu Komunikasi, FISIP, Universitas Andalas \\ Jalan Situjuh Nomor 1, Padang, Indonesia
}

\begin{abstract}
ABSTRAK
Komunikasi merupakan proses pengiriman pesan baik verbal maupun non verbal dari sumber kepada penerima melalui saluran tertentu yang bertujuan untuk mendapatkan respon yang diinginkan dan mempengaruhi perilaku penerima pesan. Dalam organisasi, komunikasi menjadi salah satu unsur terpenting untuk mempengaruhi anggota organisasi agar bekerja sama mencapai tujuan organisasi. Pimpinan merupakan penanggung jawab utama dalam organisasi yang memiliki fungsi kontrol untuk mengarahkan komunikasi dalam organisasi menjadi efektif. Komunikasi yang efektif dapat membentuk iklim komunikasi organisasi yang positif sehingga membuat karyawan termotivasi untuk berupaya mencapai tujuan organisasi. Penelitian ini bertujuan untuk mengetahui hubungan antara gaya kepemimpinan dan iklim komunikasi organisasi pada Kantor Cabang BRI Madiun di masa pandemi covid-19. Teori yang digunakan adalah Contingensy Theory yang merupakan salah satu teori komunikasi kepemimpinan yang digagas oleh Fiedler (1964). Penelitian ini menggunakan pendekatan kuantitatif dengan metode survei sebagai teknik pengumpulan data dan analisis korelasi sebagai teknik analisis data. Pengolahan data penelitian menggunakan bantuan SPSS versi 17.0. Populasi dalam penelitian ini berjumlah 107 orang, dengan pengambilan sampel menggunakan teknik simple random sampling sehingga diperoleh sampel sebanyak 85 responden. Hasil penelitian ini menunjukkan bahwa terdapat hubungan yang positif dan signifikan antara gaya kepemimpinan yang digunakan pimpinan Kantor Cabang BRI Madiun terhadap iklim komunikasi organisasi pada masa pandemi.
\end{abstract}

Kata-kata Kunci: Gaya Kepemimpinan; Iklim Komunikasi Organisasi 


\title{
RELATIONSHIP BETWEEN LEADERSHIP STYLE AND ORGANIZATIONAL COMMUNICATION CLIMATE: CASES AT BRI KANCA MADIUN DURING THE PANDEMIC
}

\begin{abstract}
Communication is the process of sending messages both verbally and non-verbally from the source to the recipient through certain channels that aim to get the desired response and influence the behavior of the recipient of the message. In organizations, communication is one of the most important elements to influence organizational members to work together to achieve organizational goals. The leader is the main person in charge in the organization who has a control function to direct communication within the organization to be effective. Effective communication can form a positive organizational communication climate so as to make employees motivated to strive to achieve organizational goals. This study aims to determine the relationship between leadership style and organizational communication climate at the BRI Madiun Branch Office during the covid-19 pandemic. The theory used is the Contingency Theory which is one of the theories of leadership communication initiated by Fiedler (1964). This study uses a quantitative approach with survey methods as a data collection technique and correlation analysis as a data analysis technique. Research data processing using SPSS version 17.0. The population in this study amounted to 107 people, with sampling using simple random sampling technique in order to obtain a sample of 85 respondents. The results of this study indicate that there is a positive and significant relationship between the leadership style used by the leadership of the BRI Madiun Branch Office on the organizational communication climate during the pandemic.
\end{abstract}

Keywords: Leadership Style, Organizational Communication Climate 
Jurnal Ilmu Komunikasi UHO : Jurnal Penelitian Kajian Ilmu Komunikasi dan Informasi.

Volume 6, No. 4, Oktober 2021, hlm 383-404

\section{PENDAHULUAN}

Dalam kehidupan sehari-hari, manusia tidak akan pernah lepas dari proses komunikasi dan interaksi antara satu dengan yang lain, baik secara individu maupun kelompok. Urgensitas komunikasi tidak hanya pada persoalan pertukaran informasi dan pesan, namun juga melingkupi kegiatan individu dan kelompok terkait pertukaran data, fakta dan ide. Melalui komunikasi, diharapkan makna yang ingin disampaikan oleh komunikator dapat diterima secara tepat oleh komunikan, sehingga terwujud saling pengertian diantara pihakpihak yang berkomunikasi.

Dalam organisasi, komunikasi merupakan salah satu alat manajemen yang berfungsi untuk mempersuasi anggota organisasi agar dapat secara bersama-sama memberikan usaha yang maksimal untuk mencapai tujuan organisasi (Mudjito dalam Nurhadi, 2017:10). Setiap organisasi tidak akan dapat berjalan tanpa adanya komunikasi di dalamnya, karena komunikasi adalah salah satu faktor kunci yang sangat berperan penting dalam menjembatani kelancaran proses interaksi dan pertukaran informasi komunikasi yang dinamis dalam setiap sistem sosial (Katz dan Kahn dalam Harjana, 2007:180). Dalam konsepsi Barnard, komunikasi memainkan peranan yang vital dalam proses pelaksanaan suatu organisasi, bukan saja melalui sistem komunikasi yang sifatnya berorientasi kepentingan organisasi, melainkan juga pada komunikasi yang disetujui secara sosial, yang senantiasa muncul dalam organisasi, dan seringkali menjadi sumber social reward yang penting bagi karyawan, serta merupakan aspek penentu dalam pelaksanaan kerja organisasi (Harjana, 2007:183).

Proses komunikasi yang berlangsung dan berkembang dalam suatu organisasi, baik formal maupun informal dapat menjadi salah satu faktor yang menentukan bagaimana hubungan dan interaksi antar anggota organisasi dalam lingkungan profesionalnya. Bahkan karena perannya yang fundamental, komunikasi diposisikan sebagai suatu iklim yang khusus yang terbentuk dalam suatu organisasi yang kemudian diberi makna oleh anggota organisasi yang berkepentingan dengannya, sehingga akan mempengaruhi cara kerja mereka (Faules dalam Nurati, 2018:76). Iklim komunikasi organisasi merupakan salah satu faktor paling berpengaruh yang menentukan daya cipta atau output organisasi, karena iklim komunikasi memberikan dampak terhadap seberapa besar usaha yang dilakukan anggota organisasi (Frantz dalam Mulyana, 2013:155). Iklim komunikasi organisasi yang positif dapat memberikan rasa percaya diri yang tinggi pada karyawan, sehingga tingkat usaha yang dihasilkanpun menjadi tinggi (Frantz dalam Nurati, 2018:76). Sebaliknya, pola dan perilaku kerja anggota organisasi yang sebelumnya baik dapat menurun apabila hubungan komunikasi 
Jurnal Ilmu Komunikasi UHO : Jurnal Penelitian Kajian Ilmu Komunikasi dan Informasi.

Volume 6, No. 4, Oktober 2021, hlm 383-404

dan interaksi yang terbentuk antar anggota organisasi tersebut tidak baik dan tidak saling mendukung, sehingga akan berdampak pada usaha anggota organisasi dalam berpartisipasi untuk mencapai tujuan organisasi (Pace dan Faules dalam Mulyana, 2013:154).

Iklim komunikasi organisasi sangat berpengaruh pada anggota organisasi, baik itu sebagai faktor pendorong untuk meningkatkan kinerjanya atau sebagai self moving yang membentuk tingkah laku mereka. Menurut Guzley dalam Saleh, (2016:191), iklim komunikasi dalam organisasi yang terdiri dari persepsi atas unsur organisasi dan pengaruh unsur tersebut terhadap komunikasi, secara berkesinambungan menghasilkan serangkaian pernyataan yang mengendalikan dan mengarahkan individu-individu dalam organisasi mengambil keputusan dan tindakan untuk berkinerja secara efektif, berkomitmen dalam organisasi untuk mengambil peluang dalam organisasi dengan spirit yang tinggi dan saling support dengan sesama anggota organisasi untuk menghasilkan kinerja terbaik bagi kepentingan dan keberhasilan organisasi. Perubahan iklim komunikasi dalam organisasi akan berdampak pada tingkat motivasi kerja karyawan dan mempengaruhi pesan-pesan individu mengenai organisasi (Mulyana, 2013:149).

Pada dasarnya, iklim komunikasi dalam suatu organisasi merupakan gabungan dari persepsi-persepsi (baik persepsi positif maupun persepsi negatif) mengenai pengalaman komunikasi anggota organisasi yang meliputi feedback pegawai terhadap pegawai lainnya, ekspektasi, konflik antar individu, dan peluang untuk berkembang dalam organisasi tersebut (Saleh, 2016:190). Iklim komunikasi organisasi terdiri dari pandangan dan pendapat atas unsur-unsur organisasi dan pengaruh unsur-unsur tersebut terhadap komunikasi (Mulyana, 2013:149). Iklim komunikasi dapat berubah-berubah tergantung pada perubahan persepsi anggota organisasi mengenai pesan dan peristiwa yang terjadi dalam organisasi (Mulyana, 2013:147).

Salah satu peristiwa yang mungkin terjadi dalam organisasi adalah krisis. Krisis merupakan suatu peristiwa yang tidak terelakkan yang dapat hadir dalam daur hidup organisasi. Krisis dapat terjadi kapanpun, dimanapun, dalam situasi apapun yang kadangkala tanpa didahului dengan peringatan apapun. Merujuk pada rumusan yang dibuat oleh Regester dan Larkin, krisis merupakan suatu kondisi yang berpotensi menyebabkan suatu organisasi menjadi highlight topic di kalangan luas, dimana kondisi tersebut dapat mengakibatkan organisasi tersebut dalam posisi yang kurang baik dalam pandangan pihak eksternal organisasi, menjadi sorotan berbagai media dan kelompok lain yang berkepentingan (stakeholder seperti konsumen, pemegang saham, karyawan, politisi, dan lainnya), yang 
Jurnal Ilmu Komunikasi UHO : Jurnal Penelitian Kajian Ilmu Komunikasi dan Informasi.

Volume 6, No. 4, Oktober 2021, hlm 383-404

karena suatu alasan tertentu memiliki ketertarikan terhadap segala kegiatan yang dilakukan oleh perusahaan (dalam Puspitasari, 2016:21).

Krisis tidak hanya disebabkan oleeh faktor-faktor internal organisasi terkait dengan strategi dan pendekatan yang dilakukan manajemen dalam organisasi, namun juga dapat berasal dari faktor eksternal di luar organisasi yang sulit diprediksi dan dikontrol oleh organisasi, seperti pengaruh globalisasi dan adanya bencana (Puspitasari, 2016:5). Namun demikian, sekalipun krisis datang secara mendadak, cara organisasi dalam menghadapi, mengelola dan menangani krisis tersebut, menjadi faktor penentu yang akan mempengaruhi penilaian dan persepsi dari para pemangku kepentingan terhadap organisasi tersebut (Puspitasari, 2016:11). Efektivitas komunikasi dengan para pemangku kepentingan, mulai dari awal munculnya krisis hingga permasalahan yang timbul akibat krisis, menjadi faktor utama yang menentukan persepsi positif ataupun negatif dari para pemangku kepentingan tersebut (Imran, 2017:38). Persepsi positif atau negatif dari anggota organisasi sebagai salah satu pemangku kepentingan dalam organisasi, akan menentukan iklim komunikasi organisasi yang tercipta.

Selain keterampilan atau teknik-teknik komunikasi, iklim komunikasi organisasi merupakan faktor yang jauh lebih penting dalam menciptakan suatu organisasi yang efektif (Redding dalam Mulyana, 2013:148). Sebagai salah satu aspek yang memiliki fungsi kegiatan dalam organisasi, iklim komunikasi organisasi memberi makna kepada anggota organisasi terkait kepercayaan yang diberikan organisasi terhadap mereka sehingga mereka dapat bertanggung jawab dalam penyelesaian tugas dan pekerjaan mereka, mempertimbangkan risiko atas setiap tindakan mereka dalam organisasi, memberikan mereka dukungan untuk menghasilkan kinerja terbaik, memberi akses yang cukup dalam pertukaran informasi mengenai organisasi, memberikan atensi terhadap informasi yang benar dan dapat dipercaya dari anggota organisasi secara maksimal, secara rutin memberikan anggota organisasi sosialisasi dan penyuluhan, dengan demikian anggota organisasi dapat menilai dan merasakan besarnya kesempatan yang diberikan oleh organisasi untuk mereka dapat terlibat dalam kepentingan organisasi dan memberikan penilaian yang objektif berdasarkan hasil dan kualitas pekerjaan mereka dan memberi tantangan (Redding dalam Mulyana, 2013:154).

Iklim komunikasi dalam suatu organisasi dapat berubaha oleh karena berbagai faktor, salah satunya adalah pengaruh pemimpin organisasi. Pola perilaku pemimpin organisasi dapat menunjang efektifitivas komunikasi yang membentuk iklim komunikasi dalam suatu organisasi, sehingga membuat karyawan termotivasi untuk mengupayakan usaha yang 
Jurnal Ilmu Komunikasi UHO : Jurnal Penelitian Kajian Ilmu Komunikasi dan Informasi.

Volume 6, No. 4, Oktober 2021, hlm 383-404

maksimal dalam mencapai tujuan organisasi (Harjana, 2007: 187-188). Pimpinan sebagai pihak yang memiliki tanggung tawab utama dalam organisasi, dapat berkontribusi dalam menciptkan iklim komunikasi yang baik bagi organisasi yang ia pimpin, melalui pola sikap dan perilaku tertentu (Muhammad, 2014:91).

Menurut Witherspoon, kepemimpinan menjadi sebuah hal yang inheren dengan iklim komunikasi dalam sebuah organisasi, yang memiliki fungsi sebagai mekanisme kontrol yang mengarahkan iklim komunikasi secara holistik, sehingga tercapai kesepahaman makna secara konsensus (Saleh, 2016:182). Unsur pimpinan dalam suatu organisasi berperan dalam membentuk dan mengontrol hubungan dan pola komunikasi di antara setiap anggota organisasi serta mendukung aktifitas-aktifitas dan upaya-upaya yang dibutuhkan dalam rangka mencapai tujuan dan prestasi organisasi (Barnard dalam Harjana, 2007:182). Pemimpin organisasi memiliki tanggung jawab atas penyediaan iklim yang sesuai (providing the right climate), karena apapun yang dilakukan oleh pemimpin pasti memberikan dampak tertentu pada iklim (Higgins dalam Novlindah, 201:48).

Menurut Hardjana, pengaruh pemimpin bersumber dari kepribadian dan gaya kepemimpinannya (dalam Novlindah, 2014:48). Gaya kepemimpinan merupakan pola tingkah laku dan kombinasi perilaku komunikatif yang digunakan seorang pemimpin dalam menanggapi keadaan di sekelilingnya dalam rangka membantu anggota organisasi (Novlindah, 2014:48) menyatakan bahwa gaya kepemimpinan yang berbeda-beda akan mempengaruhi produktivitas organisasi dan iklim komunikasi organisasi yang terbentuk. Dalam perannya membentuk iklim komunikasi organisasi, gaya kepemimpinan menjadi salah satu elemen kunci, yakni dilihat berdasarkan bagaimana pemimpin organisasi memperlakukan karyawannya, bagaimana sikap pemimpin dalam membuat keputusan, membuat kebijakan, merumuskan peraturan dalam organisasi, menyusun pola kerja dan segala bentuk aturan lainnya yang melibatkan proses komunikasi yang pada akhirnya menentukan dinamika iklim komunikasi yang terjadi dalam suatu organisasi (Harjana, 2007:181).

Efektivitas komunikasi kepemimpinan sering kali diperoleh akibat keberhasilan pemimpin dalam memilih perilaku komunikasinya secara tepat sesuai dengan kondisi. Berdasarkan teori komunikasi kepemimpinan yang dikembangkan oleh Fiedler (dalam Mulyana, 2013:289) yang disebut dengan Contingensy Theory, efektivitas komunikasi kepemimpinan ditentukan oleh kesesuaian antara gaya kepemimpinan dengan situasinya. Dalam situasi organisasi yang cukup baik dan harmonis, akan lebih efektif apabila pemimpin 
Jurnal Ilmu Komunikasi UHO : Jurnal Penelitian Kajian Ilmu Komunikasi dan Informasi.

Volume 6, No. 4, Oktober 2021, hlm 383-404

menerapkan gaya kepemimpinan yang cenderung berorientasi terhadap hubungan dengan karyawan. Sementara gaya kepemimpinan yang berorientasi terhadap tugas, akan lebih efektif digunakan dalam dua situasi, yakni situasi organisasi yang amat baik dan harmonis serta situasi yang amat tidak harmonis. Fiedler berpendapat bahwa dengan demikian, dalam menghadapi krisis yang merupakan suatu keadaan yang tidak stabil dan dapat mengancam keberadaan organisasi, gaya kepemimpinan dengan orientasi tugas akan lebih efektif diterapkan. Dengan demikian gaya kepemimpinan yang tepat dapat memberikan kontribusi dalam membangkitkan iklim komunikasi organisasi sehingga mempengaruhi perilaku anggota organisasi dan secara tidak langsung ikut membantu karyawan dalam mencapai kepuasan kerjanya (Muhammad, 2014:91).

Bank Rakyat Indonesia merupakan organisasi atau badan usaha milik pemerintah yang menghimpun dana dari masyarakat dalam bentuk simpanan dan menyalurkannya kepada masyarakat dalam bentuk kredit dan/atau bentuk lainnya dalam rangka meningkatkan taraf hidup rakyat banyak. Dalam catatan Bank Dunia pada tahun 2020, berdasarkan riset yang dilakukan oleh The Banker sebagaimana terdapat pada situs cnnindonesia.com tanggal 30 Juli 2020, Indonesia mengalami pertumbuhan yang kuat dengan kenaikan modal inti yang cukup signifikan, dimana posisi tertinggi ditempati oleh Bank Rakyat Indonesia dengan kontribusi terbesar yaitu 19,2\%. Selain itu, menurut situs cnbcindonesia.com tanggal 23 Juni 2021, Bank Rakyat Indonesia juga tercatat menjadi bank dengan merek paling bernilai di Indonesia pada riset yang diterbitkan oleh Brand Finance: Banking 500 2020, dengan valuasi merek Bank Rakyat Indonesia ditaksir mencapai US\$ 3,5 miliar atau senilai Rp 52,4 triliun.

Berdasarkan informasi dari laman website resminya bri.co.id, Bank Rakyat Indonesia memiliki visi menjadi The Most Valuable Bank di Asia Tenggara dan Home to the Best Talent. Upaya-upaya yang dilakukan Bank Rakyat Indonesia untuk mendukung pencapaian tujuan tersebut antara lain (1) memberikan kinerja terbaik dengan mengutamakan pelayanan kepada segmen mikro, kecil dan menengah untuk menunjang peningkatan ekonomi masyarakat; (2) memberikan pelayanan prima kepada nasabah melalui sumber daya manusia yang profesional, teknologi informasi yang handal, dan jaringan kerja yang produktif dengan prinsip operational dan risk management excellent; dan (3) bekerja dengan optimal dan baik kepada pihak-pihak dengan prinsip keuangan berkelanjutan dan praktik Good Corporate Governance yang baik. Oleh karena itu diperlukan kerjasama dan koordinasi yang baik di internal organisasi Bank Rakyat Indonesia (BRI), sehingga segala strategi dan kegiatan dapat terlaksana sesuai dengan rencana dan harapan organisasi. 
Jurnal Ilmu Komunikasi UHO : Jurnal Penelitian Kajian Ilmu Komunikasi dan Informasi.

Volume 6, No. 4, Oktober 2021, hlm 383-404

Kemunculan wabah virus Covid-19 di Indonesia pada awal tahun 2020 menyebabkan peristiwa tersebut menjadi salah satu krisis dengan skala yang luas atau landscape-scale yang dimaknai sebagai peristiwa besar yang tidak terduga yang terjadi dengan kecepatan luar biasa, sehingga mengakibatkan tingkat kepastian tinggi yang menimbulkan disorientasi, perasaan kehilangan kendali, dan gangguan emosi yang kuat (Sidik dan Sutoyo, 2020:69). Sebagaimana disampaikan oleh Direktur Jenderal Organisasi Kesehatan Dunia (WHO), virus Covid-19 secara resmi telah dinyatakan sebagai pandemi, selain berdampak pada sektor kesehatan, pandemi ini juga mempengaruhi perekonomian, sosial dan kestabilan suatu negara. Pandemi virus Covid-19 menimbulkan banyak ketidakbiasaan dan ketidakpastian, sehingga harus dihadapi dengan langkah yang tepat dan penyesuaian besar oleh banyak organisasi di Indonesia, salah satunya organisasi pada sektor perbankan.

Kantor Cabang Bank BRI Madiun merupakan salah satu unit vertikal Bank Rakyat Indonesia yang berada di Zona Merah penyebaran virus Covid-19 yang merasakan dampak dari pandemi tersebut. Menurut Manajer Operasional Kantor Cabang Bank BRI Madiun pada 3 Juni 2021, terpaparnya sebagian besar pegawai oleh virus Covid-19 bahkan sempat mengakibatkan penutupan sementara Kantor Cabang Bank BRI Madiun dan menyebabkan proses bisnis organisasi berubah mengikuti arahan pemerintah setempat yakni bekerja dari rumah (work from home). Kondisi ini tentunya menyebabkan kekhawatiran yang berlebihan serta mengakibatkan kondisi psikis dan emosial pegawai tidak stabil. Bekerja dari rumah menjadi suatu kebiasaan baru yang butuh penyesuaian. Proses komunikasi yang sebelumnya didominasi oleh interaksi langsung berubah menjadi komunikasi secara virtual. Hal yang tidak biasa ini secara otomatis akan mempengaruhi persepsi anggota organisasi mengenai apa yang ada atau terjadi di lingkungan internal organisasi yang berdampak pada iklim komunikasi organisasi yang terbentuk pada Kantor Cabang Bank BRI Madiun. Oleh karena itu dibutuhkan peran pimpinan organisasi menciptakan iklim komunikasi organisasi yang positif dan kondusif sehingga dapat mendorong seluruh jajaran agar tetap berkomitmen untuk meningkatkan performa kerja dalam situasi apapun dalam rangka mencapai tujuan organisasi.

Penelitian terkait pengaruh gaya kepemimpinan terhadap iklim komunikasi organisasi diantaranya dilakukan oleh Mustafa (dalam Novlindah, 2014:48) mengenai The Influence of Leadership Styles on Communication Climate: A Case Study of Madrasah's Management in Singapore, menunjukkan bahwa gaya kepemimpinan memiliki hubungan yang signifikan terhadap iklim komunikasi organisasi. Hasil penelitian menunjukkan bahwa gaya kepemimpinan people-oriented memiliki korelasi signifikan terhadap iklim komunikasi 
Jurnal Ilmu Komunikasi UHO : Jurnal Penelitian Kajian Ilmu Komunikasi dan Informasi.

Volume 6, No. 4, Oktober 2021, hlm 383-404

terbuka, sebaliknya gaya kepemimpinan task-oriented memiliki korelasi signifikan dengan iklim komunikasi tertutup. Demikian juga dengan hasil penelitian yang dilakukan oleh Rangarajan (dalam Diana, 2020:8) menunjukkan bahwa gaya kepemimpinan secara nyata menjelaskan terjadinya variasi pada iklim komunikasi organisasi.

Berdasarkan latar belakang pemikiran, penelitian terdahulu dan permasalahan yang ditemukan di lapangan sebagaimana dikemukakan di atas, maka penulis berusaha mengidentifikasi masalah dalam penelitian ini, yakni untuk mencari tahu apakah terdapat hubungan antara gaya kepemimpinan dan iklim komunikasi organisasi di masa pandemi Covid-19 pada Kantor Cabang Bank BRI Madiun. Adapun tujuan yang ingin dicapai dalam penelitian ini adalah untuk mendeskripsikan gaya kepemimpinan dan iklim komunikasi organisasi pada Kantor Cabang Bank BRI Madiun di masa pandemi Covid-19, serta untuk mengetahui hubungan antara gaya kepemimpinan dengan iklim komunikasi organisasi pada Kantor Cabang Bank BRI Madiun di masa pandemi Covid-19.

Hasil penelitian ini diharapkan dapat memberikan manfaat akademis maupun manfaat praktis. Dari segi akademis, penelitian ini diharapkan dapat memberikan sumbangan pemikiran dalam pengembangan kajian ilmu komunikasi dan dinamikanya, serta menjadi bahan rujukan untuk penelitian berikutnya mengenai komunikasi organisasi, terutama yang berkaitan dengan gaya kepemimpinan dan iklim komunikasi organisasi pada masa krisis. Secara praktis, hasil penelitian diharapkan dapat memberikan informasi yang otentik bagi Bank Rakyat Indonesia sebagai bahan masukan dan evaluasi dalam mencapai tujuan organisasi di masa krisis.

Berdasarkan latar belakang dan rumusan masalah dapat dirumuskan hipotesis sebagai berikut:

$\mathrm{H}_{0}$ : Tidak terdapat hubungan yang positif dan signifikan antara Gaya Kepemimpinan (X) dengan Iklim Komunikasi Organisasi (Y) pada Kantor Cabang Bank BRI Madiun di masa pandemi;

$\mathrm{H}_{1}$ : Terdapat hubungan yang positif dan signifikan antara Gaya Kepemimpinan (X) terhadap Iklim Komunikasi Organisasi (Y) pada Kantor Cabang Bank BRI Madiun di masa pandemi.

\section{METODE PENELITIAN}

Penelitian ini menggunakan pendekatan kuantitatif dengan metode survei ekplanatif yang bersifat asosiatif, dengan maksud menjelaskan hubungan (korelasi) antar variabel. 
Jurnal Ilmu Komunikasi UHO : Jurnal Penelitian Kajian Ilmu Komunikasi dan Informasi.

Volume 6, No. 4, Oktober 2021, hlm 383-404

Penelitian kuantitatif pada prinsipnya adalah untuk meneliti populasi atau sampel tertentu, pengumpulan data menggunakan instrumen penelitian, analisis data bersifat kuantitatif/statistik, dengan tujuan untuk menggambarkan dan menguji hipotesis yang telah ditetapkan (Sugiyono, 2017). Adapun lokasi penelitian berada di Jalan Pahlawan Nomor 50 Kota Madiun tepatnya pada Kantor Cabang Bank BRI Madiun.

Dalam penelitian ini, data yang digunakan dalam penelitian ini terdiri dari data primer dan data sekunder. Data primer diperoleh dari jawaban responden terhadap kuesioner yang dibagikan melalui google form kepada responden yang dipilih oleh peneliti dan diukur dengan menggunakan skala Likert dengan rentang nilai dari 1 hingga 4 (Sugiyono, 2017). Sedangkan data sekunder diperoleh dari berbagai sumber yang yang relevan dan studi dokumentasi terhadap literatur yang berkaitan dengan masalah dalam penelitian ini seperti profil Kantor Cabang Bank BRI Madiun dan dokumen data publikasi organisasi.

Adapun variabel-variabel yang akan diteliti terdiri dari variabel gaya kepemimpinan sebagai variabel independen dan variabel iklim komunikasi organisasi sebagai variabel dependen. Variabel-variabel penelitian tersebut diukur dengan menggunakan skala Likert yaitu skala yang digunakan untuk mengukur sikap, pendapat dan persepsi seseorang atau kelompok orang tentang kejadian atau gejala sosial (Sugiyono, 2017:15).

Untuk menentukan operasionalisasi pengukuran variabel penelitian di lapangan diperlukan penegasan definisi operasional variabel sehingga dapat memberikan arahan mengenai informasi-informasi apa saja yang perlu diperoleh di lapangan terkait variabel penelitian. Dalam penelitian ini, yang dimaksud dengan gaya kepemimpinan adalah pola perilaku yang diterapkan pemimpin dalam bekerja pada suatu organisasi, sebagai hasil kombinasi dari falsafah, keterampilan, sifat, dan sikap yang bertujuan untuk mendapatkan umpan balik dan mempengaruhi kinerja bawahannya.

Menurut Likert (1961) dalam Harjana (2007:188-191), gaya kepemimpinan secara umum terdiri dari dua dimensi, yaitu gaya kepemimpinan yang berorientasi tugas dan gaya kepemimpinan yang berorientasi hubungan. Adapun indikator gaya kepemimpinan berdasarkan kedua dimensi gaya kepemimpinan tersebut, antara lain terdiri dari: (1) kepercayaan terhadap bawahan; (2) sikap dalam memotivasi bawahan; (3) perhatian terhadap pendapat bawahan; (4) keterbukaan komunikasi; dan (5) pengendalian terhadap bawahan.

Sedangkan iklim komunikasi organisasi merupakan gabungan dari persepsi-persepsi mengenai suatu peristiwa komunikasi, perilaku, respon pegawai satu dengan pegawai lainnya, ekspektasi (harapan), berbagai pertentangan antar individu, dan kesempatan bagi 
Jurnal Ilmu Komunikasi UHO : Jurnal Penelitian Kajian Ilmu Komunikasi dan Informasi.

Volume 6, No. 4, Oktober 2021, hlm 383-404

pertumbuhan dalam organisasi. adapun indikator iklim komunikasi menurut Pace dan Faules dalam Mulyana (2013:159-160), antara lain terdiri dari: (1) kepercayaan; (2) pembuatan keputusan bersama; (3) kejujuran; (4) keterbukaan dalam komunikasi ke bawah; (5) mendengarkan dalam komunikasi ke atas; dan (6) perhatian pada tujuan berkinerja tinggi.

Dalam penelitian ini, yang akan dijadikan populasi adalah seluruh pegawai Kantor Cabang Bank BRI Madiun yang berjumlah 107 orang dan terdaftar dalam sistem informasi kepegawaian Bank Rakyat Indonesia, tidak termasuk Pimpinan Kantor Cabang Bank BRI Madiun. Untuk proses pengambilan sampel dalam penelitian ini dilakukan menggunakan teknik Random Sampling, yaitu teknik sampling yang memberi peluang yang sama bagi setiap unsur (anggota) populasi untuk dipilih menjadi anggota sampel (Sugiyono, 2017:149). Untuk menentukan ukuran sampel dari populasi dalam penelitian ini, peneliti menggunakan rumus Yamane yakni sebagai berikut:

$$
n=\frac{N}{1+N(e)^{2}}
$$

Keterangan:

$$
\begin{aligned}
& \mathrm{n} \quad=\text { jumlah sampel yang diperlukan } \\
& \mathrm{N} \quad=\text { jumlah populasi } \\
& \mathrm{d}^{2} \quad=\text { tingkat kesalahan yang sampel (desired margin of error), } \\
& \text { dalam penelitian ini digunakan 5\% yang berarti tingkat keyakinan (level of } \\
& \text { confidence) } 95 \%
\end{aligned}
$$

Berdasarkan rumus di atas diperoleh jumlah sampel sebagai berikut:

$$
\begin{aligned}
n & =\frac{N}{1+N\left(e^{) 2}\right.}=\frac{107}{1+(107) \cdot(0,05)^{2}} \\
& =\frac{107}{1,268}=84,384=85 \text { responden }
\end{aligned}
$$

Selanjutnya, data dalam penelitian ini diolah dan dianalisis secara statistik dengan menggunakan bantuan program SPSS (Statistical Package for the Social Science) versi 17. Menurut Sugiyono (2017:226), analisis data merupakan kegiatan setelah data dari seluruh responden terkumpul, diantaranya mengelompokkan data berdasarkan variabel dan jenis responden, mentabulasi data berdasarkan variabel dari seluruh responden, menyajikan data tiap variabel yang diteliti, melakukan perhitungan untuk menjawab rumusan masalah, dan melakukan perhitungan untuk menguji hipotesis yang telah diajukan. 
Jurnal Ilmu Komunikasi UHO : Jurnal Penelitian Kajian Ilmu Komunikasi dan Informasi.

Volume 6, No. 4, Oktober 2021, hlm 383-404

Sebelum kuesioner sebagai alat pengumpulan data penelitian disebarkan kepada seluruh responden, terlebih dahulu dilakukan uji validitas untuk mengetahui ketepatan instrumen penelitian, dan uji reliabilitas untuk mengukur keandalan alat ukur yang digunakan dalam penelitian ini. Uji validitas dan uji reliabilitas dalam penelitian ini dilakukan dengan bantuan program SPSS. Kuesioner tersebut terdiri dari 28 instrumen penelitian, dengan rincian 15 pernyataan untuk variabel x (gaya kepemimpinan), dan 13 pernyataan untuk variabel y (iklim komunikasi organisasi) yang kemudian diujikan kepada 30 sampel.

Penelitian ini menggunakan uji validitas dengan tingkat signifikansi sebesar 0,05 dengan kriteria pengujian yaitu jika $r$ hitung > $r$ tabel, maka skor butir pernyataan valid. Berdasarkan tabel nilai r Product Moment (Sugiyono, 2017:530), diketahui nilai koefisien korelasi tabel ( $\mathrm{r}$ tabel) untuk jumlah sampel sebanyak 31 sampel sebesar 0,361. Adapun hasil uji validitas terhadap variabel $\mathrm{x}$ dan variabel $\mathrm{y}$ tersebut dijelaskan pada Tabel 1 sebagai berikut:

Tabel 1. Hasil Uji Validitas Variabel X dan Variabel Y

\begin{tabular}{|c|c|c|c|c|c|}
\hline \multirow{2}{*}{ Item } & \multirow{2}{*}{ r tabel } & \multicolumn{2}{|c|}{ Variabel X } & \multicolumn{2}{c|}{ Variabel Y } \\
\cline { 3 - 6 } & & r hitung & Ket & r hitung & Ket \\
\hline 1 & 0,361 & 0,736 & Valid & 0,739 & Valid \\
\hline 2 & 0,361 & 0,742 & Valid & 0,745 & Valid \\
\hline 3 & 0,361 & 0,732 & Valid & 0,746 & Valid \\
\hline 4 & 0,361 & 0,745 & Valid & 0,735 & Valid \\
\hline 5 & 0,361 & 0.739 & Valid & 0,750 & Valid \\
\hline 6 & 0,361 & 0,742 & Valid & 0,738 & Valid \\
\hline 7 & 0,361 & 0,743 & Valid & 0,738 & Valid \\
\hline 8 & 0,361 & 0,728 & Valid & 0,740 & Valid \\
\hline 9 & 0,361 & 0,744 & Valid & 0,742 & Valid \\
\hline 10 & 0,361 & 0,731 & Valid & 0,755 & Valid \\
\hline 11 & 0,361 & 0,731 & Valid & 0,756 & Valid \\
\hline 12 & 0,361 & 0,734 & Valid & 0,755 & Valid \\
\hline 13 & 0,361 & 0,732 & Valid & 0,753 & Valid \\
\hline 14 & 0,361 & 0,733 & Valid & - & - \\
\hline 15 & 0,361 & 0,748 & Valid & - & - \\
\hline
\end{tabular}

Sumber: Data Olahan SPSS Tahun 2021

Dari tabel diatas diketahui $r$ hitung seluruh instrumen penelitian untuk variabel $\mathrm{x}$ dan variabel y lebih besar dari nilai $r$ tabel. Dapat disimpulkan bahwa keseluruhan item pernyataan dinyatakan valid dan layak digunakan untuk mengukur variabel-variabel dalam penelitian ini.

Untuk uji reliabilitas, penelitian ini menggunakan uji statistik Cronbach's Alpha dimana melalui uji statistik ini dilakukan perbandingan nilai alpha dengan standarnya, dengan 
Jurnal Ilmu Komunikasi UHO : Jurnal Penelitian Kajian Ilmu Komunikasi dan Informasi.

Volume 6, No. 4, Oktober 2021, hlm 383-404

ketentuan, jika alpha $>0,6$ maka instrumen pengamatan dinyatakan reliabel. Tabel berikut adalah tabel ringkasan hasil uji reliabilitas yang dilakukan dengan menggunakan program SPSS:

Tabel 2. Hasil Uji Reliabilitas

\begin{tabular}{|c|c|c|c|}
\hline Variabel & $\begin{array}{c}\text { Nomor Item } \\
\text { Pernyataan }\end{array}$ & $\begin{array}{c}\text { Nilai } \\
\text { Alpha }\end{array}$ & Kesimpulan \\
\hline $\begin{array}{c}\text { Iklim Komunikasi } \\
\text { Organisasi }\end{array}$ & 1 s.d 15 & 0,763 & Reliabel \\
\hline Gaya Kepemimpinan & 16 s.d 28 & 0,752 & Reliabel \\
\hline
\end{tabular}

Sumber: Data Olahan SPSS Tahun 2021

Berdasarkan data hasil uji reliabilitas di atas, dapat diketahui nilai Cronbach's Alpha variabel iklim komunikasi adalah sebesar 0,763, dan variabel gaya kepemimpinan sebesar 0,913. Oleh karena nilai Cronbach's Alpha seluruh variabel yang digunakan dalam penelitian ini lebih besar dari 0,6, dapat disimpulkan bahwa seluruh pernyataan dalam kuesioner dinyatakan reliabel.

Setelah data dalam penelitian ini dinyatakan valid dan reliabel, dilakukan uji asumsi klasik terhadap data dalam penelitian ini. Uji asumsi klasik dilakukan sebelum dilakukannya pengujian hipotesis, dengan tujuan agar model regresi pada penelitian ini signifikan dan representatif. Adapun uji asumsi klasik dalam penelitian ini terdiri dari uji normalitas dan uji heteroskedastisitas. Untuk uji normalitas data digunakan uji statistik Kolmogorov-Smirnov dengan bantuan program SPSS, dimana residual dikatakan berdistribusi normal apabila nilai signifikansi asymp. Sig (2 tailed) > 0,05. Adapun hasil uji normalitas tersebut disajikan pada Tabel 3 sebagai berikut:

Tabel 3. Hasil Uji Normalitas

\begin{tabular}{|l|c|}
\hline & Unstandardized Residual \\
\hline $\mathrm{N}$ & 85 \\
\hline Kolmogorov-Smirnov Z & 0,684 \\
Asymp. Sig. (2-tailed) & 0,738 \\
\hline
\end{tabular}

Sumber: Data Olahan SPSS Tahun 2021

Berdasarkan hasil uji normalitas, diketahui nilai signifikansi asymp. Sig (2 tailed) sebesar 0,738. Oleh karena nilai tersebut lebih besar dari 0,05, maka sesuai dengan dasar pengambilan keputusan dalam uji Kolmogorov-Smirnov di atas, dapat disimpulkan bahwa data residual terdistribusi dengan normal. 
Jurnal Ilmu Komunikasi UHO : Jurnal Penelitian Kajian Ilmu Komunikasi dan Informasi.

Volume 6, No. 4, Oktober 2021, hlm 383-404

Untuk uji heteroskedastisitas, dalam penelitian ini, deteksi ada atau tidaknya heteroskedastisitas dilakukan dengan melihat Grafik Plot, apakah terdapat pola tertentu pada gambar Scatter Plot Mode antara nilai prediksi variabel terkait (ZPRED) dengan residualnya (SRESID). Hasil uji heteroskedastisitas dapat dilihat pada grafik Scatter Plot pada gambar berikut:

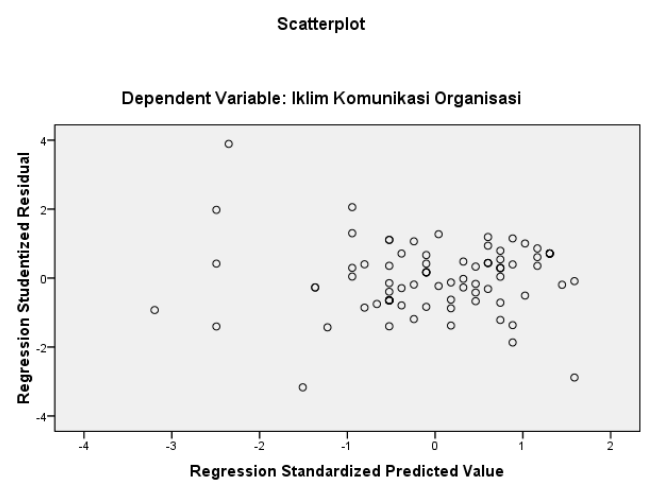

Gambar 1.1 Grafik Scatter Plot

Berdasarkan grafik Scatterplots di atas, terlihat jelas bahwa titik-titik data menyebar di atas dan di bawah angka 0, tidak berkumpul hanya di atas atau di bawah saja, serta penyebaran titik-titik data tidak berpola. Oleh karena itu dapat disimpulkan bahwa tidak terdapat gejala heteroskedastisitas.

Selanjutnya, dilakukan analisis deskriptif untuk memberi gambaran terhadap obyek yang diteliti sebagaimana adanya. Dalam penelitian ini, untuk mendeskripsikan variabel gaya kepemimpinan digunakan nilai total skor berdasarkan tanggapan responden terhadap instrumen yang terdapat pada kuesioner penelitian dengan ketentuan: (1) nilai total skor $>37,5$ s.d 60, dipandang sebagai gaya kepemimpinan berorientasi karyawan, dan (2) nilai total skor 15 s.d 37,5, dipandang sebagai gaya kepemimpinan yang berorientasi tugas. Sedangkan untuk mendeskripsikan variabel iklim komunikasi organisasi digunakan nilai ratarata dari total skor keseluruhan jawaban yang diberikan responden, yang tersusun dalam distribusi data, dengan ketentuan sebagai berikut:

Tabel 4. Kategori Rata-Rata (Mean) Instrumen

\begin{tabular}{|l|l|l|}
\hline No & Nilai Rata-rata $($ Mean) & \multicolumn{1}{|c|}{ Kategori } \\
\hline 1 & $1,00 \leq$ rata-rata $<1,76$ & Sangat rendah \\
\hline 2 & $1,76 \leq$ rata-rata $<2,51$ & Rendah \\
\hline 3 & $2,51 \leq$ rata-rata $<3,26$ & Tinggi \\
\hline 4 & $3,26 \leq$ rata-rata $=4,00$ & Sangat tinggi \\
\hline
\end{tabular}


Jurnal Ilmu Komunikasi UHO : Jurnal Penelitian Kajian Ilmu Komunikasi dan Informasi.

Volume 6, No. 4, Oktober 2021, hlm 383-404

Setelah mendapatkan deskripsi objek penelitian, dilakukan pengujian hipotesis yang merupakan pengujian terhadap suatu pernyataan dengan menggunakan metode statistik, untuk mengetahui signifikan atau tidaknya hubungan antar variabel dalam penelitian. Adapun pengujian hipotesis dalam penelitian ini dilakukan dengan menggunakan uji koefisien korelasi, dengan lima kategori interval koefisien untuk melihat seberapa kuat tingkat hubungan antar variabel masing-masing kategori tersebut sebagaimana terdapat pada Tabel 5 berikut:

\section{Tabel 5. Interpretasi Koefisien Korelasi}

\begin{tabular}{|c|l|}
\hline $\begin{array}{c}\text { Interval } \\
\text { Koefisien }\end{array}$ & \multicolumn{1}{c|}{$\begin{array}{c}\text { Tingkat } \\
\text { Hubungan }\end{array}$} \\
\hline $0,000-0,199$ & Sangat Rendah \\
\hline $0,200-0,399$ & Rendah \\
\hline $0,400-0,599$ & Sedang \\
\hline $0,600-0,799$ & Kuat \\
\hline $0,800-1,000$ & Sangat Kuat \\
\hline
\end{tabular}

\section{HASIL DAN PEMBAHASAN}

Gaya kepemimpinan merupakan seperangkat pola perilaku dan sikap pemimpin dalam mempengaruhi tingkah laku bawahannya agar sesuai dengan harapan dan keinginannya. Adapun persepsi responden terhadap gaya kepemimpinan Pimpinan Kantor Cabang Bank BRI Madiun dapat dilihat pada Tabel 6, sebagai berikut:

Tabel 6. Deskripsi Variabel Gaya Kepemimpinan

\begin{tabular}{|c|c|c|c|}
\hline No & Kategori & Frekuensi & Persentase (\%) \\
\hline 1 & Tinggi & 79 & 92,94 \\
\hline 2 & Rendah & 6 & 7,06 \\
\hline & Total & 85 & 100,00 \\
\hline
\end{tabular}

Sumber: Data Olahan Hasil Penelitian (2021)

Berdasarkan data yang disajikan pada Tabel 6 di atas, secara keseluruhan persepsi pegawai Kantor Cabang Bank BRI Madiun terhadap gaya kepemimpinan yang digunakan oleh Pimpinan Kantor Cabang Bank BRI Madiun selama masa pandemi Covid-19, sebagian besar atau 92,94\% termasuk dalam kategori tinggi, sedangkan 7,06\% lainnya menyatakan bahwa gaya kepemimpinan Pimpinan Kantor Cabang termasuk dalam kategori rendah. Hal ini mengindikasikan bahwa sebagian besar pegawai berpendapat bahwa pola perilaku yang diterapkan pemimpin dalam bekerja dan mempengaruhi kinerja bawahannya, menggunakan pola perilaku yang cenderung berorientasi pada hubungan karyawan. Dengan diterapkannya 
Jurnal Ilmu Komunikasi UHO : Jurnal Penelitian Kajian Ilmu Komunikasi dan Informasi.

Volume 6, No. 4, Oktober 2021, hlm 383-404

gaya kepemimpinan tersebut, diharapkan dapat menciptakan iklim komunikasi organisasi yang supportif dan mempengaruhi kinerja pegawai untuk mencapai visi dan misi organisasi.

Iklim komunikasi organisasi merupakan gabungan dari persepsi-persepsi mengenai suatu peristiwa komunikasi, perilaku, respon pegawai satu dengan pegawai lainnya, ekspektasi (harapan), berbagai pertentangan antar individu, dan kesempatan bagi pertumbuhan dalam organisasi. Adapun persepsi responden terhadap iklim komunikasi organisasi pada Kantor Cabang Bank BRI Madiun dapat dilihat pada Tabel 7 berikut:

Tabel 7. Deskripsi Variabel Iklim Komunikasi Organisasi

\begin{tabular}{|l|l|l|l|}
\hline No & Kategori & Frekuensi & Persentase (\%) \\
\hline 1 & Sangat tinggi & 51 & 60,00 \\
\hline 2 & Tinggi & 31 & 36,47 \\
\hline 3 & Rendah & 3 & 3,53 \\
\hline 4 & Sangat rendah & - & - \\
\hline & Total & 3,38 & 100,00 \\
\hline
\end{tabular}

Sumber: Data Olahan Hasil Penelitian (2021)

Berdasarkan data yang disajikan pada Tabel 7 di atas, secara keseluruhan persepsi pegawai Kantor Cabang Bank BRI Madiun mengenai iklim komunikasi pada Kantor Cabang Bank BRI Madiun, sebagian besar atau 60\% termasuk dalam kategori sangat baik. Sedangkan sebesar 36,47\% pegawai berpendapat bahwa iklim komunikasi organisasi tergolong dalam kategori baik, dan 3,53\% lainnya menyatakan bahwa iklim komunikasi organisasi pada Kantor Cabang Bank BRI Madiun masih termasuk dalam kategori kurang baik. Hal ini mengindikasikan bahwa sebagian besar pegawai Kantor Cabang Bank BRI Madiun memiliki persepsi yang sangat baik mengenai perilaku komunikasi yang terjadi dalam organisasi, dalam mencapai tujuan organisasi. Dengan demikian, iklim komunikasi organisasi yang baik diharapkan dapat mendorong peningkatan kinerja pegawai dalam mencapai tujuan organisasi yang telah ditetapkan, terutama pada saat menghadapi situasi krisis.

\section{Hubungan Gaya Kepemimpinan dan Iklim Komunikasi Organisasi pada Kantor Cabang Bank BRI Madiun di Masa Pandemi}

Hipotesis yang diuji dalam penelitian ini adalah tidak terdapat hubungan yang positif dan signifikan antara gaya kepemimpinan terhadap iklim komunikasi organisasi pada Kantor 
Jurnal Ilmu Komunikasi UHO : Jurnal Penelitian Kajian Ilmu Komunikasi dan Informasi.

Volume 6, No. 4, Oktober 2021, hlm 383-404

Cabang Bank BRI Madiun, diuji dengan uji koefisien korelasi menggunakan alat bantu SPSS dengan hasil uji sebagaimana disajikan pada Tabel 8 berikut:

Tabel 8

Korelasi Gaya Kepemimpinan dan Iklim Komunikasi Organisasi

\begin{tabular}{|l|l|l|l|}
\hline $\begin{array}{l}\text { Variabel } \\
\text { Independen }\end{array}$ & $\begin{array}{l}\text { Variabel } \\
\text { Dependen }\end{array}$ & $\begin{array}{l}\text { Koefisien } \\
\text { Korelasi }\end{array}$ & Sig. \\
\hline $\begin{array}{l}\text { Gaya } \\
\text { Kepemimpinan }\end{array}$ & $\begin{array}{l}\text { Iklim Komunikasi } \\
\text { Organisasi }\end{array}$ & 0,730 & 0,000 \\
\hline
\end{tabular}

Sumber: Data Olahan Hasil Penelitian (2021)

Berdasarkan Tabel 8 Korelasi Gaya Kepemimpinan dan Iklim Komunikasi Organisasi, dapat diketahui nilai signifikansi antara variabel Gaya Kepemimpinan dengan Iklim Komunikasi Organisasi adalah sebesar 0,000 $<0,05$, yang berarti bahwa terdapat korelasi yang signifikan antara Gaya Kepemimpinan dengan Iklim Komunikasi Organisasi pada Kantor Cabang Bank BRI Madiun di masa pandemi. Sedangkan untuk nilai r hitung (Pearson Correlations) adalah sebesar 0,730 > r tabel 0,207, sehingga dapat disimpulkan bahwa terdapat korelasi dengan tingkatan hubungan yang kuat, antara variabel Gaya Kepemimpinan dan Iklim Komunikasi Organisasi. Selain itu, nilai r hitung yang positif menjelaskan bahwa hubungan antara kedua variabel tersebut bersifat positif, dengan kata lain semakin tinggi/semakin baik persepsi pegawai terhadap gaya kepemimpinan, maka semakin baik pula iklim komunikasi organisasi pada Kantor Cabang Bank BRI Madiun. Nilai Pearson Correlation antara masing-masing variabel yang dihubungkan memiliki dua tanda bintang $(* *)$, yang artinya korelasi yang menghubungkan kedua variabel memiliki taraf signifikansi $5 \%$.

\section{Pembahasan}

Komunikasi merupakan sebuah proses yang mengikat kesatuan organisasi, karena komunikasi membantu anggota-anggota organisasi mencapai tujuan individu dan juga organisasi, merespon dan mengimplementasikan perubahan organisasi, mengoordinasikan aktivitas organisasi, dan ikut memainkan peran dalam hampir semua tindakan organisasi yang relevan (Romli, 2014:7). Salah satu perubahan organisasi yang tak terduga dan dapat menyerang organisasi adalah krisis. Krisis dapat menyerang korporasi, organisasi, badanbadan pemerintahan, servis, perusahaan hingga keluarga, yang dapat mengganggu aktivitas, citra dan nama baik, apabila tidak ditangani dengan baik (Barton dalam Handayani, 2018:67).

Dalam situasi krisis, penguasaan terhadap informasi, pemahaman terhadap arah pergerakan krisis, serta pengendalian terhadap situasi krisis merupakan hal-hal yang sangat 
Jurnal Ilmu Komunikasi UHO : Jurnal Penelitian Kajian Ilmu Komunikasi dan Informasi.

Volume 6, No. 4, Oktober 2021, hlm 383-404

menentukan besarnya dampak krisis tersebut terhadap organisasi (Handayani, 2018:68). Oleh karena itu, pemimpin merupakan pihak utama dalam organisasi yang memiliki wewenang untuk melakukan kontrol terhadap organisasi, berperan penting dalam menangani krisis yang dihadapi organisasi.

Kepemimpinan menggambarkan bagaimana seorang pemimpin mengarahkan pihak yang dipimpin untuk mencapai tujuan atau harapan pemimpin, melalui pola perilaku tertentu yang disebut dengan gaya kepemimpinan (Warrick dalam Novlindah, 2014:51). Gaya kepemimpinan yang tepat seringkali menentukan keberhasilan pemimpin dalam mempengaruhi bawahannya untuk bekerja secara maksimal dan memperoleh hasil yang diinginkan sesuai dengan tujuan organisasi (Novlindah, 2014:25).

Penerapan gaya kepemimpinan dalam sebuah organisasi juga sangat berpengaruh terhadap hubungan komunikasi antar anggota organisasi yang akan membentuk iklim komunikasi pada organisasi tersebut (Diana, 2020:6). Iklim komunikasi yang positif cenderung meningkatkan komitmen dan kinerja anggota dalam organisasi, sebaliknya iklim komunikasi yang negatif dapat merusak perilaku anggota organisasi dalam berpartisipasi untuk organisasi. Menurut Guzley dalam (Saleh, 2016:174) iklim komunikasi daapt memberi pedoman atas keputusan dan perilaku seseorang dalam melakukan aktivitas pekerjaan mereka secara efektif, agar dapat mengikatkan diri mereka pada organisasi, jujur dalam bekerja, untuk meraih kesempatan dalam organisasi secara bersemangat, untuk mendukung para rekan dan anggota organisasi lainnya, untuk melaksanakan tugas secara kreatif, untuk menawarkan gagasan-gagasan inovatif bagi penyempurnaan organisasi dan operasinya. Dengan kata lain, iklim komunikasi organisasi memainkan peranan sentral dalam mendorong anggota organisasi untuk mencurahkan usaha kepada pekerjaan mereka dalam organisasi.

Penelitian ini dilakukan untuk membuktikan secara empiris bahwa terdapat hubungan yang signifikan antara gaya kepemimpinan dan iklim komunikasi organisasi pada Kantor Cabang Bank BRI Madiun. Hasil penelitian ini menunjukkan bahwa terdapat hubungan yang signifikan antara gaya kepemimpinan dengan iklim komunikasi organisasi, dilihat dari nilai signifikansi antara variabel Gaya Kepemimpinan dengan Iklim Komunikasi Organisasi adalah sebesar $0,000<0,05$. Keeratan hubungan antara gaya kepemimpinan dengan iklim komunikasi organisasi berada pada tingkatan hubungan yang kuat, berdasarkan nilai $r$ hitung (Pearson Correlations) sebesar 0,730 > r tabel 0,207. Selain itu, nilai $r$ hitung yang positif menjelaskan bahwa hubungan antara kedua variabel tersebut bersifat positif, dengan kata lain 
Jurnal Ilmu Komunikasi UHO : Jurnal Penelitian Kajian Ilmu Komunikasi dan Informasi.

Volume 6, No. 4, Oktober 2021, hlm 383-404

semakin tepat gaya kepemimpinan, maka semakin baik pula iklim komunikasi organisasi pada Kantor Cabang Bank BRI Madiun.

Adanya hubungan yang positif dan signifikan antara gaya kepemimpinan dengan iklim komunikasi organisasi juga telah dibuktikan secara empiris berdasarkan hasil penelitian terdahulu. Diantaranya penelitian yang dilakukan oleh Dele et al., n.d. (2015) dengan judul Impact of Leadership Style on Organizational Climate in the Nigerian Insurance Industry. Penelitian tersebut menyelidiki dampak gaya kepemimpinan pada iklim organisasi di industri asuransi Nigeria melalui survei terhadap multi responden. Temuan berdasarkan survei mengungkapkan bahwa gaya kepemimpinan secara positif mempengaruhi iklim organisasi di industri asuransi Nigeria. Penelitian lainnya dilakukan oleh Lumbasi (2016) dengan judul The Effect of Participative Leadership Style on The Performance of Coya Senior Managers in Kenya menunjukkan bahwa gaya kepemimpinan memiliki hubungan positif yang kuat dengan iklim komunikasi organisasi. Hasil yang sama juga diperoleh melalui penelitian yang dilakukan oleh Hariyono (2018) dengan judul Pengaruh Gaya Kepemimpinan Perempuan terhadap Iklim Komunikasi dan Kinerja Pegawai Pada Dinas Sosial Kabupaten Aceh Tamiang, juga menunjukkan bahwa gaya kepemimpinan perempuan yang mampu mengarahkan, membimbing dan mengatur bawahan dengan baik serta mampu membangun suasana kekeluargaan dalam organisasi ternyata mampu menciptakan dan memberikan iklim komunikasi yang positif serta dapat meningkatkan kinerja pegawai yang bik pula.

Selain itu, hasil penelitian Mustafa (dalam Novlindah, 2014:48) mengenai The Influence of Leadership Styles on Communication Climate: A Case Study of Madrasah's Management in Singapore, menunjukkan bahwa gaya kepemimpinan memiliki hubungan yang signifikan terhadap iklim komunikasi organisasi. Hasil penelitian menunjukkan bahwa gaya kepemimpinan people-oriented memiliki korelasi signifikan terhadap iklim komunikasi terbuka, sebaliknya gaya kepemimpinan task-oriented memiliki korelasi signifikan dengan iklim komunikasi tertutup. Demikian juga dengan hasil penelitian yang dilakukan oleh Rangarajan (dalam Diana, 2020:8) menunjukkan bahwa gaya kepemimpinan secara nyata menjelaskan terjadinya variasi pada iklim komunikasi organisasi.

Berdasarkan hasil penelitian dalam penelitian ini dan hasil penelitian pada penelitian terdahulu, maka penelitian mengenai hubungan gaya kepemimpinan dengan iklim komunikasi organisasi penting dilakukan, terutama pada lingkungan Bank Rakyat Indonesia sebagai salah satu upaya dalam menciptakan suasana kerja yang nyaman dan hubungan yang positif antar anggota organisasi, sehingga dapat mendorong pegawai untuk meningkatkan 
Jurnal Ilmu Komunikasi UHO : Jurnal Penelitian Kajian Ilmu Komunikasi dan Informasi.

Volume 6, No. 4, Oktober 2021, hlm 383-404

performa kerja dalam mencapai tujuan organisasi dan memenuhi capaian target yang telah diamanahkan Dengan demikian, hasil penelitian ini diharapkan memiliki manfaat bagi Bank Rakyat Indonesia, khususnya Kantor Cabang Bank BRI Madiun dalam mempersiapkan sumber daya manusianya agar lebih perform serta memiliki kemampuan dan kemauan bekerja yang lebih maksimal, sehingga dapat mencapai tujuan yang telah ditetapkan organisasi dalam segala situasi.

\section{SIMPULAN}

Berdasarkan hasil penelitian yang telah dilakukan, diketahui bahwa gaya kepemimpinan yang digunakan Pimpinan Kantor Cabang Bank BRI Madiun termasuk dalam kategori tinggi yaitu gaya kepemimpinan yang cenderung berorientasi terhadap hubungan pegawai. Sedangkan untuk iklim komunikasi organisasi, sebagian besar pegawai Kantor Cabang Bank BRI Madiun menyatakan bahwa iklim komunikasi pada Kantor Cabang Bank BRI Madiun sudah sangat baik. Hasil penelitian ini menunjukkan bahwa terdapat hubungan yang signifikan antara gaya kepemimpinan dan iklim komunikasi organisasi dengan tingkatan hubungan yang kuat. Selain itu hubungan antara kedua variabel tersebut bersifat positif, dengan kata lain semakin baik gaya kepemimpinan, semakin meningkat pula kinerja pegawai Iklim Komunikasi Organisasi pada Kantor Cabang Bank BRI Madiun.

Berdasarkan pembahasan dan simpulan terhadap hasil penelitian dalam penelitian ini, Bank Rakyat Indonesia agar lebih memperhatikan pola perilaku dan komunikasi pemimpin melalui gaya kepemimpinan yang tepat sehingga dapat mempengaruhi terciptanya iklim komunikasi organisasi yang dapat mendorong peningkatan kinerja pegawai dalam mencapai tujuan organisasi. Bagi akademisi, hasil penelitian ini diharapkan dapat dijadikan referensi untuk mengembangkan penelitian selanjutnya dengan cakupan yang lebih luas dan lebih baik, dengan menambahkan variabel lain seperti kepuasan komunikasi, motivasi, budaya organisasi dan variabel-variabel lainnya, sebagai variabel yang dapat mempengaruhi iklim komunikasi organisasi. 
Jurnal Ilmu Komunikasi UHO : Jurnal Penelitian Kajian Ilmu Komunikasi dan Informasi.

Volume 6, No. 4, Oktober 2021, hlm 383-404

\section{DAFTAR PUSTAKA}

Dele, A. O., Nanle, M., \& Abimbola, O. S. (n.d.). Impact of Leadership Style on Organizational Climate in the Nigerian Insurance Industry. 8.

Diana, N. (2020). Pengaruh Gaya Kepemimpinan dan Iklim Komunikasi Organisasi terhadap Tingkat Disiplin Kerja Pegawai yang Dimediasi oleh Tingkat Motivasi Kerja Pegawai di Lembaga Layanan Pendidikan Tinggi (LLDIKTI) Wilayah VI Jawa Tengah [PhD Thesis]. Master Program in Communication Science.

Handayani, R. H. (2018). Gaya Komunikasi dan Kepemimpinan dalam Menangani Krisis Organisasi:

Studi pada Kepemimpinan Badan Pemeriksa Keuangan Periode 2004-2009 dan 2009-2014. Jurnal Komunikasi Indonesia, 67-75-75. https://doi.org/10.7454/jki.v5i1.8314

Hariyono, H. (2018). Pengaruh Gaya Kepemimpinan Perempuan Terhadap Iklim Komunikasi Dan Kinerja Pegawai Pada Dinas Sosial Kabupaten Aceh Tamiang. JURNAL SIMBOLIKA: Research and Learning in Communication Study, 4(2), 73-85. https://doi.org/10.31289/simbollika.v4i2.1819

Harjana, A. (2007). Iklim Komunikasi Keorganisasian. Jurnal Ilmu Komunikasi, 4(2), 179-231.

Imran, A. I. (2017). Komunikasi Krisis. Yogyakarta: Deepublish.

Lumbasi, G. W. (2016). The Effect Of Participative Leadership Style On The Performance Of COYA Senior Managers In Kenya. 4(5), 12.

Muhammad, A. (2014). Komunikasi Organisasi. Jakarta: Bumi Aksara.

Mulyana, D. (2013). Komunikasi Organisasi: Strategi Meningkatkan Kinerja Perusahaan. Bandung: PT Remaja Rosdakarya.

Novlindah. (2014). Pengaruh Gaya Kepemimpinan dan Iklim Komunikasi terhadap Kinerja Anggota Tim (Studi pada Tim Audit AKN II BPK RI [University of Indonesia]. http://lib.ui.ac.id/

Nurati, D. E. (2018). Iklim Komunikasi Organisasi dalam Menciptakan Manajemen Reputasi di PT PLS Area Surakarta.. Seminar Nasional Ilmu Komunikasi Politik 2018, 1.

Nurhadi, Z. F. (2017). Teori Komunikasi Kontemporer. Jakarta: Kencana.

Puspitasari. (2016). Komunikasi Krisis: Strategi Mengelola dan Memenangkan Citra di Mata Publik. Jakarta: Penerbit Libri.

Romli, K. (2014). Komunikasi Organisasi Lengkap. Jakarta: PT Grasindo.

Saleh, A. M. (2016). Komunikasi dalam Kepemimpinan Organisasi. Malang: Universitas Brawijaya Press.

Sugiyono. (2017). Metode Penelitian Kuantitatif dan Kualitatif. Bandung: CV. Alfabeta. 
Jurnal Ilmu Komunikasi UHO : Jurnal Penelitian Kajian Ilmu Komunikasi dan Informasi.

Volume 6, No. 4, Oktober 2021, hlm 383-404

Lainnya:

CNN Indonesia. (30 Agustus 2020). BRI, Bank Terbaik Indonesia di Daftar Top 1.000 World Banks. https://www.cnnindonesia.com/ekonomi/20200730205004-83-530865/bri-bankterbaik-indonesia-di-daftar-top-1000-world-banks diakses tanggal 5 Juli 2021

CBNC Indonesia. (23 Juni 2021). BRI Kembali Jadi Merek Bank Paling Bernilai di Indonesia. https://www.cnbcindonesia.com/market/20210623155310-17-255392/bri-kembalijadi-merek-bank-paling-bernilai-di-indonesia diakses tanggal 5 Juli 2021

Bank BRI. https://bri.co.id/info-perusahaan diakses tanggal 5 Juli 2021 